\title{
REASONS FOR SATISFACTION AND DISSATISFACTION OF BANK CUSTOMERS. STUDY FROM SLOVAKIA AND THE CZECH REPUBLIC
}

\author{
Jaroslav BELÁS ${ }^{1}$, Lenka GABČOVÁ2
}

\begin{abstract}
The satisfaction of bank customers presents an important area of building long-term relationships with the client, which significantly determines the financial performance of commercial banks through successful business. This article presents the current situation in the banking sector in the Czech Republic and Slovakia. The aim of this article is to measure the customer satisfaction, its development in time, then to determine the main satisfaction and dissatisfaction attributes and finally to compare the situation in the Czech Republic and Slovakia. To measure all these elements, standard statistical methods have been used. The observed overall satisfaction rate of the Czech and Slovak clients is very similar. The main reason for the satisfaction of bank customers in both countries is ability to use electronic banking and most important reason for their dissatisfaction is long-term high prices of products and services.
\end{abstract}

\section{KEY WORDS}

commercial banks, customers' satisfaction, attributes of customers' satisfaction and dissatisfaction

\section{JEL CLASSIFICATION}

G 21

\section{INTRODUCTION}

The customer satisfaction should be perceived as the basis of the financial performance of a bank. It is probable that satisfied customers will continue purchasing its products or even recommend this bank to other potential clients.

As a result, it is particularly important to maintain customer satisfaction in relation to a financial performance and competitiveness of commercial banks.

\footnotetext{
${ }^{1}$ Correspondence address: assoc. prof. Ing. Jaroslav Belás, PhD., Department of Enterprise Economics, Faculty of Management and Economics, Tomas Bata University in Zlin, Mostní 5139, 76001 Zlin, Czech Republic; email: belas111@gmail.com

${ }^{2}$ Correspondence address: Bc. Lenka Gabčová, Department of Enterprise Economics, Faculty of Management and Economics, Tomas Bata University in Zlin, Mostní 5139, 76001 Zlin, Czech Republic; email: 1.gabcova@fame.utb.cz
} 
According to Ernst \& Young (2011, p.3), the overall confidence of clients in the banking industry has been significantly reduced thus the contacts with their clients through the improvement of bank products and services have to be re-established by banks. It is important for banks to find an effective way to pay attention to clients individually and be able to distinguish and analyze financial needs of clients.

In this context it is essential to analyze the development of customer satisfaction in banks and individual attributes of client satisfaction or dissatisfaction in the Slovak banking sector at the time of intense impact of various critical factors. In this article, the results from Slovakia have been compared with the current situation in the Czech Republic.

\section{IMPORTANT ATTRIBUTES OF CUSTOMER SATISFACTION IN A COMMERCIAL BANK}

Munari, Ielasi and Bajetta (2013), Chavan and Ahmad (2013) indicate that the customer satisfaction is becoming a stable goal of banking market policies, an important element for strengthening corporate reputation and the most critical aspect to corporate banking success.

Many authors such as Croxford, Abramson and Jablonowski (2002) examine satisfaction attributes of bank customers and consider that the dominant attributes are service quality, brand and price. In this context, Wruuck (2013) states that prices play a central role for customer satisfaction and profitability. Especially in the current situation, marked by cost pressure and changing customer expectations, pricing is thus of particular importance. The satisfaction with product pricing does not automatically mean the overall and complete satisfaction, but it is only one of the most important requirements.

According to Berry (2005), dominant attributes of customer satisfaction are an understanding of client financial needs, an active offer of attractive products and feeling to be appreciated in a bank.

Chakrabarty (2006) defined four factors of customer satisfaction related with the branch (speed of service, attitude of employees, privacy, opening hours), economic satisfaction (level of charges, interest rates), satisfaction with remote access (dial-up or internet banking) and availability of ATMs.

Lages and Piercy (2012) argue that customers require a high level of acceptance of their own needs and accurate provision of services from the bank employees.

Chavan and Ahmad (2013) state the eight most important attributes of customer satisfaction:

- individual attention to every customer,

- staff behavior leading to trust,

- attractive environment in a bank branch,

- outstation cheques free of charge,

- error-free records,

- online banking possibilities,

- safety of transactions,

- employees' willingness to answer the questions even during the busy periods.

Choudhury (2013) state that customers distinguish four dimensions of service quality: behavior, reliability, tangibles and convenience. 
Maddern, Maull and Smart (2007) examined the relationship between customer satisfaction depending on employee satisfaction and a service quality in the banking sector. Results of this study confirmed a high correlation between employee satisfaction and customer satisfaction.

Baumann, Elliott and Burton (2012) examined the loyalty of bank customers which was based on the overall satisfaction, emotional attitudes towards banks, service quality, perception of the market situation (costs and benefits of the change) and customer characteristics.

Mandahachitara and Poolthang (2011) indicated that customer loyalty is crucial because gaining new customers entails more costs and vice versa, longer duration of a relationship with a customer brings higher profitability to a bank. Loyalty is thus a key element of long-term profits for any company, including banks. According to the research of Fraering and Minor (2013) held in the USA, satisfied, cognitive, affective and active loyalty are positively related to fortitude.

The profit and a company growth are primarily stimulated through customer loyalty which is directly formed by their satisfaction. Customer satisfaction is determined by service quality that creates satisfied, loyal and productive employees (Gelade and Young, 2005; Saura, Contrí, Taulet and Velasquez, 2005). Seiler, Rudolf, and Krume (2013) found out that the service value has no significant direct effect on customer loyalty; the impact of service value on customer loyalty is completely mediated by customer satisfaction.

However, there are also papers arguing that neither customer satisfaction nor loyalty have a significant impact on the financial performance of banks, while the remaining factors have indicated unprecedented results (Keisidou, Sarigiannidis, Maditinos, and Thalassinos, 2013).

Dimensions of service quality are employee behavior, tangibility and information technology. Dimensions of service convenience are decision convenience, access convenience, transaction convenience, benefit convenience and post-benefit convenience. (Kaura, 2013)

The survey of Ernst \& Young (2012) indicates that banks do not really recognize customer needs and do not adjust bank products to these needs according to customer opinions. The reason to suggest so is that only $44 \%$ of respondents worldwide believe that their bank adjusts their products to their needs. The most important impulse to change the bank is the amount of charges as $53 \%$ of European clients would change their main bank precisely because of this fact. The second most important reason is bad experience in a bank's branch.

According to Deloitte research (2012), only 17\% of respondents in the Czech Republic and 12\% of clients in Poland changed the bank in the past or they have their accounts in two different banks. In comparison, $52 \%$ of respondents of the same survey conducted in Slovakia have moved their accounts to another bank (28\% in Hungary and $42 \%$ in Romania). Ernst \& Young (2011) argues that European bank customers change their banks primarily because of poor quality services (48\%) and because of high prices (43\%).

Judging from all these findings measuring the customer satisfaction and its development together with their purchasing habits could be considered as crucial for improving of the performance of a bank.

In our opinion, it is important to continue carrying out research on these aspects of the development in the banking sectors of Slovakia and the Czech Republic and to compare the findings. These two countries are closely linked: they have common history and cooperate in creating the legislation of their banking sectors. As a result, they are compared in numerous international comparisons. 


\section{RESEARCH OBJECTIVES AND USED METHODOLOGY}

The aim of this article is to measure the customer satisfaction, its development in time and the number of purchased banking products, then to determine the main satisfaction and dissatisfaction attributes and finally to compare the situation in Slovakia and the Czech Republic.

The research of customer satisfaction has been conducted by a questionnaire survey. The survey has been developed on the basis of results of foreign studies and our own knowledge of this issue (Chakrabarty, 2006; Berry, 2005; Croxford, Abramson a Jablonowski, 2002).

Random sampling method was used in the data collection process.

Our first research on customer satisfaction in Slovakia was conducted in 2008 on the sample of 298 respondents. Four years later, in October 2012, the research was carried out again. The research included a total of 320 respondents of which $55 \%$ were women and $45 \%$ men. The age structure of respondents was as follows: $23 \%$ of respondents were in the category up to 30 years, $59 \%$ were between $30-50$ years and $18 \%$ of them were more than 50 years. $89 \%$ of respondents were employed, $5 \%$ were unemployed and $6 \%$ were retired. The educational level of respondents was as follows: $6 \%$ of them had primary education, $48 \%$ reported high school education and $46 \%$ reported a university education.

The same questionnaire was distributed in the Czech Republic, where 323 respondents have been approached. $37.46 \%$ of them were males and $62.54 \%$ were females. The age structure of respondents was as follows: $31.58 \%$ of them are under the age of 30 years, $50.46 \%$ are at the age of 30 to 50 years and $17.96 \%$ of them were respondents above the age of 50 . The education structure of respondents was as follows: $0.93 \%$ - primary education, $61.61 \%$ - secondary education and $37.46 \%$ - university education.

In 2014, responses were received from 459 respondents, of which $44 \%$ were men and $56 \%$ were women. The age structure of those respondents was as follows: $39 \%$ of respondents were aged under 30, $44 \%$ were aged from 31 to 50 years and $17 \%$ of them were customers over 50 . The education level of respondents was as follows: $3 \%$ had primary education, $54 \%$ had secondary education and $43 \%$ were university educated bank customers.

In this last research, three scientific hypotheses have been set. By determining the quantitative criteria, the method of expert estimate has been used.

H1: The overall level of satisfaction of bank customers in Slovakia has decreased during the financial crisis and it was not different from the overall level of satisfaction of bank customers in the Czech Republic in 2012. The overall satisfaction of bank customers in the Czech Republic has not changed between 2012 and 2014.

H2: The main attribute of satisfaction of Slovak bank customers has changed during the crisis. The most important attribute of satisfaction has become the possibility to use electronic banking. This attribute was more important in the banking sector of the Czech Republic in 2012 in comparison to Slovakia.

H3: High prices of products and services have remained the most important attribute of dissatisfaction of Slovak bank customers. In the banking sector of the Czech Republic, the situation was similar. 
The associations in contingency tables were analyzed by Pearson statistics for data count. In the cases, where of asymptotic requirements for the test were violated; series of 5000 Monte Carlo replications from original data has been conducted.

P-value is being compared with the standard 5\% confidence level. If P-value lower than the confidence level this leads to the rejection of the null hypothesis. The null hypothesis claims there is no association between variables. Calculations have been performed in statistical packages XL Statistics and R.

\section{RESULTS AND SHORT DISCUSSION}

The development of the overall customer satisfaction in Slovak banking sector during the crisis and the current situation in the Czech Republic are shown in Table 1.

\section{Table 1. The development of the overall customer satisfaction in Slovakia (SR) and the Czech Republic (CR)}

\begin{tabular}{|c|c|c|c|c|c|}
\hline $\begin{array}{l}\text { Question: Are you } \\
\text { satisfied with provided } \\
\text { bank products and } \\
\text { services? }\end{array}$ & $\begin{array}{c}\text { SR } \\
2012 \\
\text { in } \%\end{array}$ & $\begin{array}{c}\text { SR } \\
2008 \\
\text { in } \%\end{array}$ & $\begin{array}{l}\text { CR } \\
2014 \\
\text { in } \%\end{array}$ & $\begin{array}{c}\text { CR } \\
2012 \\
\text { in } \%\end{array}$ & p-value \\
\hline 1. Yes & 61 & 64 & 66 & 62 & $\begin{array}{r}0.5182 * \\
1.0000 * * \\
0.2819 * * * \\
\end{array}$ \\
\hline 2. No & 23 & 21 & 16 & 26 & $\begin{array}{r}1.0000 \\
1.0000 \\
<0.01 \\
\end{array}$ \\
\hline 3. I do not know & 16 & 16 & 18 & 12 & $\begin{array}{l}1.0000 \\
1.0000 \\
0.0275 \\
\end{array}$ \\
\hline$\chi^{2}=0.6930 / 2.2823 / 14.2141$ & \multicolumn{3}{|c|}{$\mathrm{p}$-value $=0.7293 / 0.3195 /<0.01$} & & \\
\hline
\end{tabular}

Note: p-value* - comparison of the results in 2008 and 2012 in Slovakia, p-value** - comparison of the Czech Republic and Slovakia in 2012, p-value*** - comparison of the results in 2012 and 2014 in the Czech Republic

By using a test of dependence in pivot table $(\chi 2=0.693$, $p$-value $=0.7293)$, the change of overall level of customer satisfaction in Slovak banking sector has not been proved.

Based on results of our research it can be stated that the overall satisfaction in both countries does not differ significantly $(\chi 2=2.2823$, p-value $=0.3195)$ in the year 2012 .

The research in 2014 showed that the overall satisfaction of the Czech bank customers have not changed within the last two years. Thus the validity of $\mathrm{H} 1$ has been confirmed partially.

According to results of our research, the overall level of the satisfaction of Czech customers is at European diameter. These results are comparable to some published results of the satisfaction of banks' clients. For example, the average value of the satisfaction was $62 \%$ in the Great Britain in 2012 (www.dailymail.co.uk). According to results of the research of Deloitte (2012), the overall level of the satisfaction in the Czech Republic, Slovakia and Poland is 50\% and more.

Table 2 shows the contribution of various attributes to the overall satisfaction of bank customers in Slovakia and the Czech Republic. 
Table 2. Attributes of customer satisfaction in Slovakia (SR) and the Czech Republic (CR)

\begin{tabular}{|c|c|c|c|c|c|}
\hline $\begin{array}{l}\text { What are you most satisfied in the } \\
\text { bank with?(you can specify up to } 3 \\
\text { reasons) }\end{array}$ & $\begin{array}{c}\text { SR } \\
2012 \\
\text { in } \%\end{array}$ & $\begin{array}{c}\text { SR } \\
2008 \\
\text { in } \%\end{array}$ & $\begin{array}{l}\text { CR } \\
2014 \\
\text { in } \%\end{array}$ & $\begin{array}{l}\text { CR } \\
2012 \\
\text { in } \%\end{array}$ & p-value \\
\hline 1. Fast service at the branch & 28 & 22 & 12 & 14 & $\begin{array}{r}0.1040^{*} \\
<0.01 * * \\
0.3770 * * *\end{array}$ \\
\hline $\begin{array}{l}\text { 2. The possibility to use the electronic } \\
\text { banking }\end{array}$ & 67 & 49 & 79 & 75 & $\begin{array}{l}<0.01 \\
0.0308 \\
0.1900\end{array}$ \\
\hline 3. Quality products and services & 22 & 17 & 17 & 18 & $\begin{array}{l}0.1433 \\
0.2520 \\
0.9500\end{array}$ \\
\hline $\begin{array}{l}\text { 4. Comfortable and friendly service at } \\
\text { the branch }\end{array}$ & 20 & 25 & 21 & 17 & $\begin{array}{l}0.1636 \\
0.3850 \\
0.8140\end{array}$ \\
\hline 5. The availability of branches & 53 & 45 & 51 & 50 & $\begin{array}{l}0.0565 \\
0.4999 \\
0.7910 \\
\end{array}$ \\
\hline 6. Developed network of ATMs & 28 & 54 & 42 & 40 & $\begin{array}{r}<0.01 \\
<0.01 \\
0.6670\end{array}$ \\
\hline $\begin{array}{l}\text { 7. Other (quality consulting, services } \\
\text { without charges) }\end{array}$ & 4 & 21 & 5 & 0 & $\begin{array}{l}<0.01 \\
<0.01\end{array}$ \\
\hline
\end{tabular}

Note: p-value* - comparison of the results in 2008 and 2012 in Slovakia, p-value** - comparison of the Czech Republic and Slovakia in 2012, p-value*** - comparison of the results in 2012 and 2014 in the Czech Republic, - value could not be calculated.

The values of the test criteria have shown that the attributes of customer satisfaction in Slovakia have changed. In 2012, the majority of customers declared that the main attribute of their satisfaction is the possibility to use e-banking in the interaction with their banks. The results of the test of proportions have shown a statistically significant growth of importance of this factor during the times of the financial crisis. The major attribute of satisfaction of Slovak bank clients in 2008 was the developed network of ATMs. As the Table 2 shows, the significance of this factor has substantially decreased during the crisis.

As for Czech bank clients, the major attribute of satisfaction was also the possibility to use electronic banking. Compared to the situation in Slovakia, Czech bank clients increasingly indicated this possibility in 2012 ( $\mathrm{p}$-value=0.0308). The structure of the attributes did not change dramatically in 2014 in comparison to the year 2012 in the Czech Republic. Electronic banking remains the major driver of the customer satisfaction in both countries. Hypothesis 2 was thus confirmed.

On the opposite, Table 3 shows the development of attributes of customer dissatisfaction in the Slovak and Czech banking sector.

The drivers of customer dissatisfaction in the Slovak banking sector have not changed significantly during the reported period. High prices of bank products and services remained the most important reason of client dissatisfaction. P-value has not confirmed a significant change of this reason in the reported period. 
Table 3. Attributes of customer dissatisfaction in Slovakia and the Czech Republic

\begin{tabular}{|c|c|c|c|c|c|}
\hline $\begin{array}{l}\text { What are you most dissatisfied } \\
\text { in the bank with? (you can } \\
\text { specify up to } 3 \text { reasons) }\end{array}$ & $\begin{array}{c}\text { SR } \\
2012 \\
\text { in } \%\end{array}$ & $\begin{array}{c}\text { SR } \\
2008 \\
\text { in } \%\end{array}$ & $\begin{array}{c}\text { CR } \\
2014 \\
\text { in } \%\end{array}$ & $\begin{array}{l}\text { CR } \\
2012 \\
\text { in \% }\end{array}$ & p-value \\
\hline 1. Slow service in the branch & 38 & 36 & 19 & 23 & $\begin{array}{r}0.6664 * \\
<0.01 * * \\
0.2180 * * * \\
\end{array}$ \\
\hline 2. Poor e-banking facilities & 3 & 8 & 4 & 2 & $\begin{array}{l}0.0103 \\
0.6093 \\
0.1142\end{array}$ \\
\hline $\begin{array}{l}\text { 3. High price policy of products } \\
\text { and services }\end{array}$ & 63 & 59 & 64 & 65 & $\begin{array}{l}0.3490 \\
0.8782 \\
0.7241\end{array}$ \\
\hline 4. Poor availability of branches & 11 & 8 & 6 & 10 & $\begin{array}{l}0.2581 \\
0.8782 \\
0.0910\end{array}$ \\
\hline 5. Impersonal approach & 19 & 16 & 15 & 14 & $\begin{array}{l}0.3822 \\
0.0996 \\
0.5944\end{array}$ \\
\hline 6. Low acceptance of my needs & 8 & 11 & 17 & 13 & $\begin{array}{l}0.2557 \\
0.0597 \\
0.1933\end{array}$ \\
\hline $\begin{array}{l}\text { 7. Others (personnel arrogance, } \\
\text { abuse of financial illiteracy of } \\
\text { clients) }\end{array}$ & 3 & 6 & 18 & 0 & 0.1068 \\
\hline
\end{tabular}

Note: p-value* - comparison of the results in 2008 and 2012 in Slovakia, p-value** - comparison of the Czech Republic and Slovakia in 2012, p-value*** - comparison of the results in 2012 and 2014 in the Czech Republic

- value could not be calculated.

Our research has shown there is no statistically significant difference between the values of the most important reasons of dissatisfaction (prices of products and services) in the Czech Republic and Slovakia in 2012.

The level of the dissatisfaction with high prices of products and services remained stable in the Czech Republic within the two last years. Other factors have also kept similar levels, except for the "other" possibility. 18\% of the respondents in the research in 2014 declared their dissatisfaction with another attribute than one of the proposed. Some of these were low interest rates or pushy marketing at the branch.

Judging from all the mentioned above, we can accept $\mathrm{H} 3$.

According to research by Ernst \& Young (2012) a definite number one impulse for change of bank is the amount of bank charges. $69 \%$ of the Czech bank clients would change their main operational bank because of high costs (compared to a European average of 53\%).

Due to the financial crisis customers prefer transparency and simplicity, which applies not only to the products themselves, but also for their price. Since customers currently have a strong need to 
search for information themselves, a bank that offers something to them in a clear and accessible form, gaining a competitive advantage. (Wruuck, 2013)

\section{CONCLUSIONS}

The research on customer satisfaction in Slovak banking sector proved that the perceived level of overall satisfaction slightly decreased during the crisis and it is comparable to the situation in the Czech Republic. During the reporting period, there were no significant changes in the overall satisfaction of bank customers in Slovakia and Czech Republic detected.

Electronic banking has become the most significant distribution channel of commercial banks in Slovakia during the crisis. This distribution channel is the most preferred in the Czech Republic as well. Czech clients showed a significantly higher preference for this reason of satisfaction in comparison to Slovak customers in 2012.

On the opposite, the most important attribute of customer dissatisfaction remains a high price policy of bank products and services. In both countries a relatively high level of dissatisfaction with this factor was found there. The level of dissatisfaction with this factor in the observed period did not change significantly.

Our research, like other researches on this topic has been somewhat limited by the number of respondents. Nevertheless, it is expected, that it may be beneficial for inspiration of banking executives to improve attributes of satisfaction and loyalty of bank employees.

Our future research will focus on the quantification of the effects of satisfaction growth and increase of level of loyalty of banking clients to grow the financial performance of commercial banks through growth in sales of banking products to satisfied customers.

\section{Acknowledgements}

Authors are thankful to the Internal Grant Agency of FaME TBU No. 005/IGA/FaME/2014: Optimization of Parameters of the Financial Performance of Commercial Banks, for its financial support to carry out this research.

\section{REFERENCES}

Baumann, CH., Elliott, G., Burton, S. (2012) Modelling customer satisfaction and loyalty: survey data versus data mining. Journal of Services Marketing, 26(3): 148 - 157.

Berry,J. (2005) Franchising in Retail Financial Services. VRL Publishing Ltd.

Croxford, H., Abramson, F., Jablonowski, A. (2006) The art of better retail banking. England, Chichester: John Wiley \& Sohs, Ltd.

Deloitte. (2012). Pro̊zkum: Více než čtyři pětiny Čechů jsou věrní své bance. Tlačová správa, 14.6.2012. Available from: http://www.deloitte.com/view/cs_CZ/cz/press/pressreleases /9563e3bf3cae7310Vg nVCM2000001b56f00aRCRD.htm, [cit. 2012-04-10]

Ernst \& Young. (2012) Nová éra bankovnictví. Čeští klienti chtějí, aby banky vyšly vice vstřic jejich potřebám. Praha, Tlačová správa, 25.6.2012. [cit. 2012-12-10] Cited from: http://www.ey.com/CZ/cs/Newsroom/News-releases/2012_Nova-era-bankovnictvi

Ernst \& Young. (2011) Bankovníctvo sa vo vyspelých krajinách stretáva s klesajúcou dôverou klientov. Bratislava, Tlačová správa, 22.3.201. [cit. 2012-12-10] Cited 
from: http://www.ey.com/Publication/vwLUAssets/2011_Retail_banking_SK/\$FILE/TS_\%20R etailove\%20bankovnictvo_SK.pdf

Fraering, M., Minor, M. S. (2013) Beyond loyalty: customer satisfaction, loyalty and fortitude. Journal of Services Marketing, 27(4): 334 - 344.

Gelade, G., A., Young, S. (2005) Test of a service profit chain model in the retail banking sector. Journal of Occupational and Organizational Psychology, 78: 1 - 22.

Chakrabarty, A. (2006) Barking up the wrong tree-factors influencing customer saficfaction in retail banking in the UK. International Journal of Applied Marketing, 1(1): 29 - 45.

Chavan, J., Ahmad, F. (2013) Factors Affecting On Customer Satisfaction in Retail Banking: An Empirical Study. International Journal of Business and Management Invention, 2(1): $\quad 55-62$.

Choudhury, K. (2013) Service quality and customers' purchase intentions: an empirical study of the Indian banking sector. International journal of bank marketing, 31(7): 529 - 543.

Kaura, V. (2013) Antecedents of customer satisfaction: a study of Indian public and private sector banks. International Journal of Bank Marketing, 31(3): 167 - 186.

Keisidou, E., Sarigiannidis, L., Maditinos, D. I., Thalassinos, E.I. (2013) Customer satisfaction, loyalty and financial performance: A holistic approach of the Greek banking sector. International Journal of Bank Marketing, 31(4): 259 - 288.

Lages, C. R., Piercy, N. F. (2012) Key Drivers of Frontline Employee Generation of Ideas for Customer Service Improvement. Journal of Service Research, 15(2): 215 - 230.

Maddern, H., Maull, R., Smart, A. (2007) Customer satisfaction and service quality in UK financial services. International Journal of Operations \& Production Management, 27(9): $\quad 999-1019$.

Mandahachitara, R., Poolthan, Y. (2011) A model of customer loyalty and corporate social responsibility. Journal of Service Marketing, 25(2): 123 - 133.

Munari, L., Ielasi, F., Bajetta, L. (2013) Customer satisfaction management in Italian banks. Qualitative Research in Financial Market, 5(2): 139 - 160.

Saura, I. G., Contrí, G. B., Taulet, A.C., Velazquez, B. M. (2005) Relationships among customer orientation, service orientation and job satisfaction in financial services. Journal of Service Management, 16(5): 497 - 520.

Seiler, V., Rudolf, M., Krume, T. (2013) The influence of socio-demographic variables on customer satisfaction and loyalty in the private banking industry. International Journal of Bank Marketing, 31(4): 235 - 258.

Wruuck, P. (2013) Pricing in retail banking. Scope for boosting customer satisfaction \& profitability. Deutsche Bank AG: Frankfurt am Main. [cit. 2013-9-14] Cited from: www.dbresearch.com

http://www.daily.co.uk/news/article2204076/Banks urged customers major high street chains rank low satisfaction stakes. html [cit. 2012-9-14] 
BANK CUSTOMERS SATISFACTION SURVEY IN SLOVAKIA (AND THE CZECH REPUBLIC???)

1. Gender
Male
Female

2. What is your status?
Single
Married
Other

3. You are:
Employed
Unemployed
Other

4. How old are you?
Under 30 years
Between 30 and 50 years
Above 50 years

5. What is the highest degree or level of school you have completed?
Elementary
High school
University degree

6. Are you satisfied with the products and services you use in your bank/ banks?
Yes
No
I do not know

7. What are you satisfied the most in your bank with? (you can choose up to 3 reasons)

Fast service at the branch

Quality products and services

The availability of branches

Other (please specify):
The possibility to use the electronic banking

Comfortable and friendly service at the branch

Developed network of ATMs

8. What are you dissatisfied the most in your bank with? (you can choose up to 3 reasons)

Slow service in the branch

High price policy of products and services

Impersonal approach

Other (please specify):
Poor e-banking facilities

Poor availability of branches

Low acceptance of my needs

\section{Thank you for your time!}

